\title{
Arterial Embolus
}

National Cancer Institute

\section{Source}

National Cancer Institute. Arterial Embolus. NCI Thesaurus. Code C111117.

The passage of an embolus from its site of formation in the arterial system to another location within the circulatory system. 